\title{
Cordyceps cicadae induces G2/M cell cycle arrest in MHCC97H human hepatocellular carcinoma cells: a proteomic study
}

\author{
Hualin Wang ${ }^{1,2}$, Jing Zhang ${ }^{1}$, Wai-Hung Sit ${ }^{1}$, Chung-Yung Jetty Lee ${ }^{1}$ and Jennifer Man-Fan Wan ${ }^{1 *}$
}

\begin{abstract}
Background: Cordyceps cicadae is a medicinal fungus that is often used for treating cancer. However, the anticancer mechanisms of C. cicadae are largely unknown. This study aims to investigate the anticancer mechanisms of $C$. cicadae against hepatocellular carcinoma cells in vitro using a proteomic approach.
\end{abstract}

Methods: Human hepatocellular carcinoma MHCC97H cells were treated with a water extract of C. cicadae $(0,100,250,500$, and $1000 \mu \mathrm{g} / \mathrm{mL})$ for $48 \mathrm{~h}$ and harvested for cell viability assays. The significant differences in protein expression between control and C. cicadae-treated cells were analyzed by two-dimensional gel-based proteomics coupled with matrix-assisted laser desorption ionization-time of flight mass spectrometry. Flow cytometry analysis was employed to investigate the cell cycle and cell death. The anticancer molecular mechanism was analyzed by whole proteome mapping.

Results: The water extract of C. cicadae $(0,100,250,500$, and $1000 \mu \mathrm{g} / \mathrm{mL})$ inhibited the growth of MHCC97H cells in a dose-dependent manner via G2/M phase cell cycle arrest with no evidence of apoptosis. Among the identified proteins with upregulated expression were dynactin subunit 2, N-myc downstream-regulated gene 1, heat shock protein beta-1, alpha-enolase isoform 1, phosphatidylinositol transfer protein, and WD repeat-containing protein 1. Meanwhile, the proteins with downregulated expression were 14-3-3 gamma, BUB3, microtubule-associated protein RP/EB family member 1, thioredoxin-like protein, chloride intracellular channel protein 1, ectonucleoside triphosphate diphosphohydrolase 5, xaa-Pro dipeptidase, enoyl-CoA delta isomerase 1, protein-disulfide isomerase-related chaperone Erp29, hnRNP 2H9B, peroxiredoxin 1, WD-40 repeat protein, and serine/threonine kinase receptor-associated protein.

Conclusion: The water extract of $C$. cicadae reduced the growth of human hepatocellular carcinoma MHCC97H cells via G2/M cell cycle arrest.

\section{Background}

Primary liver cancer accounted for $6 \%$ of the total cancer cases worldwide in 2008 [1]. The highest incidences of liver cancer were in East Asia (Japan, Korea, and China) [2,3]. In China, liver cancer has the third highest estimated agestandardized cancer incidence rate in men and the fourth in women, and the second and third highest cancer mortality rates in men and women, respectively [1]. The high incidence of liver cancer in China is attributed to consumption of aflatoxin-contaminated grains, liver virus infection, and alcohol drinking [3]. Hepatitis B vaccination can

\footnotetext{
* Correspondence: jmfwan@hku.hk

${ }^{1}$ Food and Nutrition Division, School of Biological Sciences, The University of Hong Kong, Pokfulam Road, Hong Kong, SAR, China

Full list of author information is available at the end of the article
}

effectively prevent liver cancer, but the treatment of liver cancer is still difficult $[3,4]$.

Chinese medicine (CM) has been widely used in conjunction with chemotherapeutic drugs for liver cancer treatment in China with positive outcomes [5]. Cordyceps is a genus of ascomycete fungi belonging to the Clavicipitaceae family. All Cordyceps species are endoparasitoids, and most of them parasitize insects and other arthropods. The Cordyceps genus includes nearly 400 species, and some of them have potential anticancer effects. Cordyceps sinensis is a medicinal fungus that has been used for cancer treatment in CM and Traditional Tibetan medicine since the 15 th century [6,7]. The anticancer properties of $C$. sinensis via cancer cell apoptosis induction, proliferation inhibition, or both in various 
types of cancers, including leukemia, melanoma, Leydig tumor, breast cancer, and human hepatocellular carcinoma (HCC) have been investigated [8-10]. C. sinensis inhibited tumor metastasis in vivo $[11,12]$. Another well-known species, Cordyceps militaris, showed anticancer effects on leukemia, lung cancer, and breast cancer in vitro and in vivo [13-17], and its bioactive compound, cordycepin, exhibited cytotoxic and reactive oxygen species-generating activity in relation to cancer proliferation inhibition [18-22].

Cordyceps cicadae, another well-known medicinal mushroom that grows on larvae of Cicadae flammata, has been used in CM in China for the prevention and treatment of various diseases, including kidney disease, immune disease, and cancer [23-25]. C. cicadae exhibited immunoregulatory effects on human $\mathrm{T}$ lymphocytes and modulated the growth of mononuclear cells [26-29]. C. cicadae inhibited the growth of lung adenocarcinoma and melanoma in vivo and in vitro [30,31]. However, the anticancer mechanism of C. cicadae for liver cancer is still unknown.

In the last decade, proteomics has been widely used in medical studies for clinical biomarker identification, pathogenesis investigation, new drug discovery, pharmacological research, toxicological examination, and so on [32]. Most biological functions are transmitted via proteins such as enzymes, receptors, and structural components. Therefore, comprehensive proteomic analyses help us to understand the molecular modifications in physiological conditions [33]. This study aims to investigate the anticancer mechanisms of $C$. cicadae against $\mathrm{HCC}$ in vitro by two-dimensional gel-based proteomics coupled with matrix-assisted laser desorption ionization-time of flight (MALDI-TOF/TOF) mass spectrometry (MS), flow cytometry analysis, and proteome mapping.

\section{Materials and methods \\ Cell culture and reagents}

The MHCC97H cell line was purchased from the Liver Cancer Institute of Fudan University (China). MHCC97H cells were cultured in DMEM (Gibco BRL, USA) supplemented with $10 \%$ fetal bovine serum (Gibco BRL) in a humidified incubator containing $5 \% \mathrm{CO}_{2}$ in air at $37^{\circ} \mathrm{C}$, and subcultured with $0.25 \%$ trypsin-0.02\% EDTA (Gibco BRL). A lyophilized hot water extract of wild-type C. cicadae (BioAsia Co., China) was dissolved in phosphate-buffered saline (PBS) and adjusted to a final concentration of $10 \mathrm{mg} / \mathrm{mL}$.

\section{Cell proliferation assay}

The dose-dependent effect of $C$. cicadae on cell viability was assessed by the MTT assay. Briefly, suspended MHCC $97 \mathrm{H}$ cells $\left(1 \times 10^{5}\right.$ cells $\left./ \mathrm{mL} ; 100 \mu \mathrm{L}\right)$ were dispersed into the wells of 96-well microtiter plates. After $24 \mathrm{~h}$ of incubation, various concentrations of $C$. cicadae were added to each well and incubated for 48 or $72 \mathrm{~h}$. Next, $10 \mu \mathrm{L}$ of
MTT solution (5 mg/mL 3-(4,5-dimethylthiazol-2-yl)2,5-diphenyltetrazolium bromide dissolved in c-DMEM) (USB Corporation, USA) was added to each well, and incubated for $3 \mathrm{~h}$ at $37^{\circ} \mathrm{C}$. The MTT solution was then removed and the insoluble purple formazan crystals formed were dissolved in $50 \mu \mathrm{L}$ of isopropanol in $0.1 \mathrm{M} \mathrm{HCl}$ (MERCK, Germany). The optical density (OD) of each well was measured using a Bio-Rad 550 Microplate Reader (Bio-Rad, USA) at $595 \mathrm{~nm}$ with a reference wavelength of $655 \mathrm{~nm}$. The percentage of cell viability was expressed as $\left(\mathrm{A}_{\text {treatment }} / \mathrm{A}_{\text {control }}\right) \times 100 \%$.

\section{Cell cycle analysis}

The dose-dependent effect of $C$. cicadae on the cell cycle distribution was assessed by flow cytometry as described in our previous report [34]. Briefly, MHCC97H cells $\left(1 \times 10^{5}\right.$ cells $\left./ \mathrm{mL}\right)$ were treated with various concentrations of $C$. cicadae $(0,100,250,500$, and $1000 \mu \mathrm{g} / \mathrm{mL})$ for $48 \mathrm{~h}$, and the cells were then harvested, fixed in $70 \%$ ethanol (MERCK, Germany), and stored at $-20^{\circ} \mathrm{C}$ for $24 \mathrm{~h}$ until further analysis. Next, the cells were washed twice with ice-cold PBS, and incubated with RNase and propidium iodide (PI) (Sigma-Aldrich, USA) for $30 \mathrm{~min}$. The PI-stained cells were excited at a wavelength of $488 \mathrm{~nm}$ and emitted at a maximum wavelength of $617 \mathrm{~nm}$. Acquisition of 10,000 events was chosen for measurement of the DNA cell cycle distribution using a COULTER XL Flow Cytometer (Beckman and Coulter, USA). The distribution of cells in the different cell cycle phases shown in the DNA histograms was analyzed using Becton Dickinson Cell Fit Software (BD, USA).

\section{Sample preparation for proteomic analysis}

MHCC97H cells were seeded in 100-mm culture dishes at $1 \times 10^{6}$ cells $/$ dish $\left(1 \times 10^{5}\right.$ cells $\left./ \mathrm{mL}\right)$, incubated overnight, and then treated with or without $500 \mu \mathrm{g} / \mathrm{mL} \mathrm{C}$. cicadae for $48 \mathrm{~h}$. The cells were harvested by trypsinization, washed three times with PBS, and centrifuged in a Beckman Spinchron DLX (Beckman and Coulter) at $400 \times g$ for $5 \mathrm{~min}$. The cell pellet was resuspended in lysis buffer [1\% Triton X-100 (USB Corporation), $25 \mathrm{mmol} / \mathrm{L} 4-$ (2-hydroxyethyl)-1-piperazineethanesulfonic acid (HEPES; Sigma-Aldrich), $150 \mathrm{mmol} / \mathrm{L} \mathrm{NaCl}$ (UNIVAR, USA), $1 \mathrm{mmol} / \mathrm{L}$ EDTA disodium salt (Sigma-Aldrich), $1 \mathrm{mmol} / \mathrm{L}$ dithiothreitol (DTT; USB Corporation)] with Protease Inhibitor Cocktail Set III (AEBSF, aprotinin, bestatin, E-64, leupeptin hemisulfate, pepstatin A; Bio-Rad). The superfluous salt in the extract was removed by incubation with trichloroacetic acid (TCA)-acetone solution [20\% TCA (MERCK, Germany), $20 \mathrm{mmol} / \mathrm{L}$ DTT in acetone (MERCK, Germany)] for $4 \mathrm{~h}$ at $-40^{\circ} \mathrm{C}$. The protein pellet was obtained by centrifugation at $15,800 \times g$ for $30 \mathrm{~min}$ at $4^{\circ} \mathrm{C}$. Excess TCA was removed by three washes with acetone containing $20 \mathrm{mmol} / \mathrm{L}$ DTT. The air-dried protein pellet was 
resuspended in buffer [7 $\mathrm{mol} / \mathrm{L}$ urea (USB Corporation), $2 \mathrm{~mol} / \mathrm{L}$ thiourea (Sigma-Aldrich), 4\% 3-[(3-cholamidopropyl)dimethylammonio]-1-propanesulfonate (CHAPS; Sigma-Aldrich), $100 \mathrm{mmol} / \mathrm{L}$ DTT, 5\% glycerol (USB Corporation)], and the protein solution was stored at $-80^{\circ} \mathrm{C}$ until 2-DE analysis. The protein concentration was determined by the Bradford assay (Bio-Rad).

\section{Two-dimensional electrofocusing and polyacrylamide gel electrophoresis}

The 2-DE procedures were carried as described in our previous report with modifications [35]. The samples were examined in duplicate and 12 gels ( 6 for control cells and 6 for $C$. cicadae-treated cells) were used in total. For the first-dimensional electrophoresis of proteins, protein samples $(150 \mu \mathrm{g})$ were mixed with $350 \mu \mathrm{L}$ of rehydration buffer [9.5 mol/L urea, 2\% CHAPS, 0.28\% DTT, 1\% immobilized pH gradient buffer with pH 3-10 (Bio-Rad), 0.002\% bromophenol blue (Sigma-Aldrich)] and then rehydrated for $10 \mathrm{~h}$ before isoelectric focusing via the following program: (a) linear increase up to $500 \mathrm{~V}$ in $1 \mathrm{~h}$; (b) held at $500 \mathrm{~V}$ for $2 \mathrm{~h}$; (c) linear increase up to $10,000 \mathrm{~V}$ in $4 \mathrm{~h}$; (d) linear increase up to $10,000 \mathrm{~V}$ in $3 \mathrm{~h}$; (e) held at $10,000 \mathrm{~V}$ to reach a total of $90,000 \mathrm{~V} \times \mathrm{h}$. Focused immobilized $\mathrm{pH}$ gradient (IPG) gel strips were equilibrated for $15 \mathrm{~min}$ in a solution [ $50 \mathrm{mmol} / \mathrm{L}$ Tris- $\mathrm{HCl}, \mathrm{pH} 8.8$ (Bio-Rad), 6 mol/L urea, 30\% glycerol, $2 \%$ sodium dodecyl sulfate (SDS; USB Corporation), containing $20 \mathrm{mmol} / \mathrm{L}$ DTT], followed by incubation with the same buffer containing $20 \mathrm{mmol} / \mathrm{L}$ iodoacetamide (Sigma-Aldrich) for another $15 \mathrm{~min}$. The second-dimensional separation was performed in 1 -mm-thick $12.5 \%$ polyacrylamide gels by sodium dodecyl sulfate-polyacrylamide gel electrophoresis (SDS-PAGE) at 15-mA current for $30 \mathrm{~min}$ followed by $30-\mathrm{mA}$ current for the rest of the analysis.

\section{Image acquisition and analysis}

After the electrophoresis, the gels were stained with SYPRORuby Protein Stain (Bio-Rad), scanned with a Molecular Imager PharosFX Plus System (Bio-Rad), and analyzed using PDQuest 8.0 (Bio-Rad) according to the following procedures: background subtraction, spot detection, and spot matching. The expression levels, expressed as the percentage volume (\% vol), were exported. The relative intensities of spots were used for comparisons between the two groups and only those spots with a significant difference $(>1.5$-fold increase or decrease, $P<0.05$ ) were selected for protein identification.

\section{Protein identification}

Spots with differential expression $(P<0.05)$ after $500 \mu \mathrm{g} / \mathrm{mL}$ C. cicadae treatment were sent to the Genome Research Centre (The University of Hong Kong, Hong Kong) for protein identification by MALDI-TOF/TOF MS (4800 MALDI
TOF/TOF Analyzer; Applied Biosystems, USA) analysis after trypsin digestion. The identification was performed by Mascot peptide mass fingerprinting, which can identify proteins from the NCBInr database with taxonomy limited to Homo sapiens. Mascot reported the molecular weight search (MOWSE) score, which was calculated as $-10 \times \log _{10}$ $(P)$, where $P$ is the probability that the observed match is a random event. $P$ was limited by the size of the sequence database being searched (limited by taxonomy), with conditions such as peptide fixed modification and variable modification and the settings for trypsin digestion. Each calculated value that fell within a given mass tolerance of an experimental value counted as a match. The threshold was accepted if an event occurred at random with a frequency of $<5 \%$. In this study, a protein match with a score of $>71$ was regarded as significant.

\section{Western blot analysis}

Western blot analysis was performed with Mighty Small II SE250/260 Cell (Hoefer, USA) and TE 77 PWR Transfer (GE Healthcare, USA) electrophoresis units. Briefly, $\mathrm{MHCC} 97 \mathrm{H}$ cells treated with or without various concentrations of $C$. cicadae $(0,100,250$, and $500 \mu \mathrm{g} / \mathrm{mL})$ for $48 \mathrm{~h}$ were harvested, washed twice with PBS, and lysed in the lysis buffer for sample preparation described above. The lysates were centrifuged at $11000 \times g$ for $30 \mathrm{~min}$. The total protein concentration in the supernatant was determined by the Bradford assay (Bio-Rad). For immunoblotting, each protein extract was mixed with sample buffer $[62.5 \mathrm{mmol} / \mathrm{L}$ Tris, pH 6.8 (Bio-Rad), 25\% glycerol, 2\% SDS, $350 \mathrm{mmol} / \mathrm{L}$ DTT, $0.01 \%$ bromophenol blue] at a ratio of $1: 1(\mathrm{v} / \mathrm{v})$ and then kept in boiling water for $5 \mathrm{~min}$. An aliquot (30 mg protein) of each sample was applied for electrophoresis in 12.5\% SDS-PAGE gels with constant voltage $(120 \mathrm{~V})$ and transferred to a polyvinylidene difluoride membrane (GE Healthcare). The membranes were blocked with $5 \%$ skimmed milk in PBST [PBS, pH 7.4, 0.1\% Tween-20 (USB Corporation)] for $3 \mathrm{~h}$ at room temperature, followed by incubation for $2 \mathrm{~h}$ with the following primary antibodies (ABCAM, UK): antiCDK1 (ab32384; 1:2000); anti-cyclin B1 (ab32053; 1:2000); anti-HSP27 (ab2790; 1:2000); anti-PRDX1 (ab16805; 1:2000); anti-STRAP (ab46784; 1:2000). The membranes were washed three times with PBST, and incubated with HRPconjugated goat anti-rabbit or anti-mouse IgG (Bio-Rad; 1:10 000) for $1 \mathrm{~h}$ at $37^{\circ} \mathrm{C}$. After three washes with PBST, the membranes were developed using Inmun-Star HRP peroxide buffer (Bio-Rad). The relative molecular weight of each protein band was estimated using molecular markers (Precision Plus Protein Standards Dual Color; Bio-Rad). Each sample was measured three times.

\section{Statistical analysis}

In cell proliferation assay, experiments were repeated three times, measurements within an experiment were done in 
six duplicate, and in cell cycle analysis, experiments were repeated three times. Data from three independent experiments were expressed as mean \pm standard deviation (SD). The significance of differences in data was determined by Kruskal-Wallis one-way analysis of variance (ANOVA) followed by Dunnets post hoc test for determination of dose-response dependence. In proteomic analysis, six individual samples were prepared and run for $2 \mathrm{D}$ gel in each group (i.e., $\mathrm{n}=6$ ) the significance of differences in data was determined by a two-tailed Student's $t$-test with Levene's test for equality of variances. All analyses were performed using SPSS 17.0 (IBM, USA) with $P<0.05$ as the significance level.

\section{Results}

\section{Effects of C. cicadae on MHCC97H cell proliferation}

$\mathrm{MHCC} 97 \mathrm{H}$ cells were grown in medium containing various concentrations of $C$. cicadae $(0,100,250,500$, and $1000 \mu \mathrm{g} / \mathrm{mL}$ ) for 48 or $72 \mathrm{~h}$ to investigate the effects of $C$. cicadae on cell proliferation. Dose-dependent inhibition of cell growth was observed with treatment of C. cicadae $(P<0.05)$ (Figure 1$)$.

\section{Effect of C. cicadae on the cell cycle distribution of MHCC97H cells}

Figure 2A shows the effects of $C$. cicadae $(0,100,250,500$, and $1000 \mu \mathrm{g} / \mathrm{mL}$ ) treatment for $48 \mathrm{~h}$ on the cell cycle phase distribution of MHCC97H cells. As shown in Figure 2B, treatment with $C$. cicadae (100, 250, and $500 \mu \mathrm{g} / \mathrm{mL}$ ) for $48 \mathrm{~h}$ resulted in cell accumulation in $\mathrm{G} 2 / \mathrm{M}$ phase at $23.8 \%$, $30.2 \%$, and $38.6 \%$, respectively, compared with the control cells (19.8\%), and decreased the cell percentages in G0/G1 phase by $48.2 \%, 43.9 \%$, and $35.6 \%$, respectively, compared with the control cells (53.3\%). Treatment with C. cicadae at

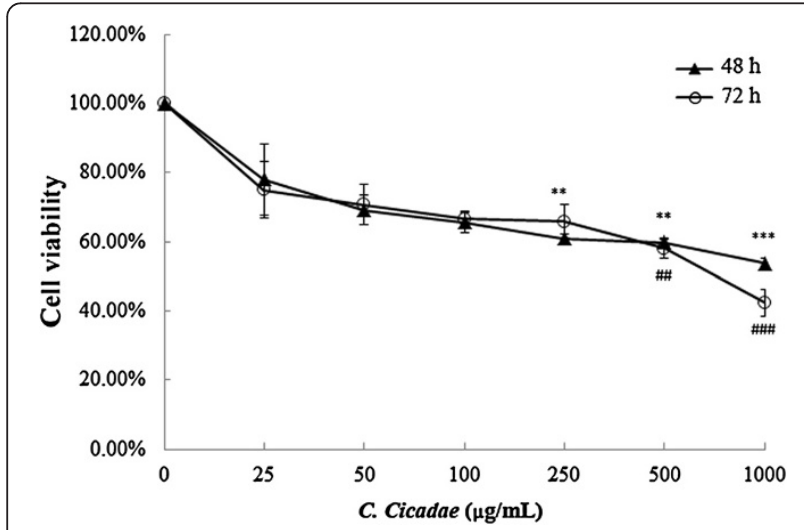

Figure 1 The effects of $C$. cicadae on MHCC97H cell viability.

The cell viability was tested by MTT assay. Data were expressed as mean $\pm S D$ ( $n=3$ separate experiments). ${ }^{* *},{ }^{* *}, P<0.01,0.001 \mathrm{vs}$. control in $48 \mathrm{~h}$ treatment group, and \#\#, \#\#, $P<0.01,0.001$ vs. control in $72 \mathrm{~h}$ treatment group, respectively.
100, 250, and $500 \mu \mathrm{g} / \mathrm{mL}$ for $48 \mathrm{~h}$ did not affect the cell population in S phase $(27.9 \%, 25.8 \%$, and $25.9 \%$, respectively, compared with the control cells (26.91\%). Furthermore, most cells (64.74\%) were arrested in G2/M phase with the highest dose of $1000 \mu \mathrm{g} / \mathrm{mL}$ C. cicadae. The sub-G1 apoptotic fraction of cells showed no significant changes when C. cicadae (100-500 $\mu \mathrm{g} / \mathrm{mL})$ was added, suggesting that no apoptosis occurred during the period of examination.

$\mathrm{CDK} 1 /$ cyclin B complex is involved in the $\mathrm{G} 2 / \mathrm{M}$ phase checkpoint by regulating the process of $M$ phase [36]. Figure 3 shows that while the CDK1 protein level was decreased in MHCC97H cells after C. cicadae treatment, the cyclin B1 protein level was unaffected.

\section{Differential expression of proteins in C. cicadae-treated MHCC97H cells}

2-DE analyses were performed for each treated sample and repeated six times. Figure 4 shows representative gel images in which more than 1000 spots were detected on each gel. Proteins within the range of $15-225 \mathrm{kDa}$ and having isoelectric points between 3 and 10 were well separated. Table 1 presents the differential expression levels of the identified proteins in MHCC97H cells without (control) and with $C$. cicadae treatment. Twenty-eight proteins with significant $(P<0.05)$ changes of $>1.5$-fold in volume intensity were selected and further analyzed by MALDI-TOF-MS/MS for peptide identification after trypsin digestion. Among these proteins, the nine upregulated proteins were identified as tubulin beta $2 \mathrm{C}$, dynactin subunit 2 (DCTN2), keratin type II cytoskeletal 7, keratin type I cytoskeletal 10, N-myc downstream-regulated gene 1 (NDRG1), heat shock protein beta-1 (HSPB1, Hsp27), phosphatidylinositol transfer protein beta isoform (PITPNB), alpha-enolase isoform 1 (ENO1), and WD repeat-containing protein 1 isoform 1 (WDR1). The 13 downregulated proteins were identified as 14-3-3 gamma (YWHAG), microtubule-associated protein RP/EB family member 1 (MAPRE1), chloride intracellular channel protein 1 (CLIC1), WD-40 repeat protein (STRAP), thioredoxin-like protein (GLRX3), ACTB protein, xaa-Pro dipeptidase isoform 3 (PEPD), enoyl-CoA delta isomerase 1 mitochondrial (ECI1), protein-disulfide isomerase-related chaperone Erp29 (ERP29), ectonucleoside triphosphate diphosphohydrolase 5 isoform (ENTPD5), hnRNP 2H9B (HNRNPH3), peroxiredoxin 1 (PRDX1), and mitotic checkpoint protein BUB3 isoform A (BUB3). The main properties of the identified proteins were summarized in Table 2.

Western blot analyses of a few randomly selected proteins were performed for proteomic data validation. In agreement with the proteome changes identified by the proteomic analysis, the expression levels of Hsp27, peroxiredoxin 1, and WD 40 were upregulated in the cancer cells with C. cicadae treatment at $500 \mu \mathrm{g} / \mathrm{mL}$ 

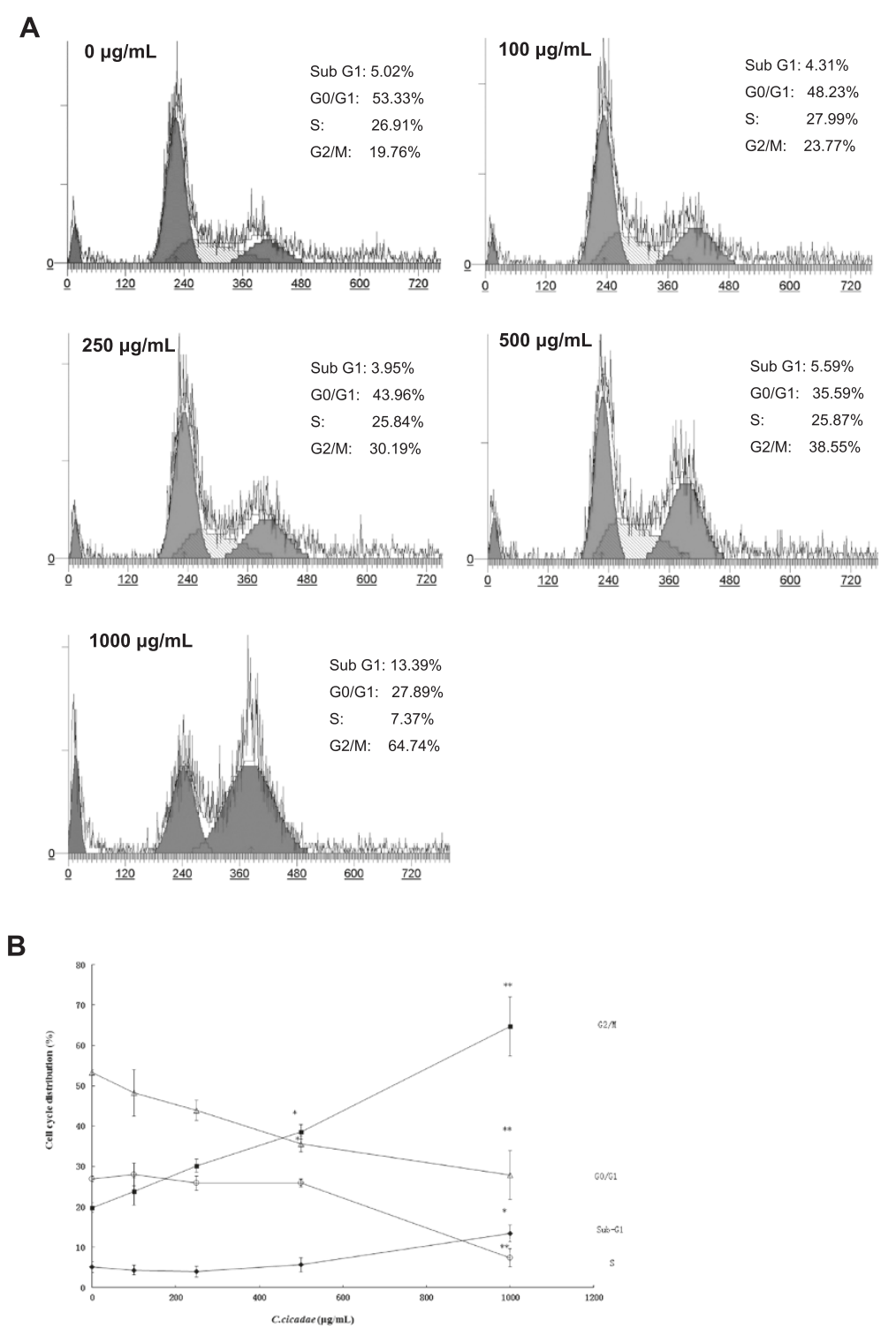

Figure 2 The effects of C. cicadae on MHCC97H cell cycle. (A) Cellular DNA contents in C. cicadae-treated and control cells were monitored by flow cytometry. The cell cycle distribution of sub-G1, G1, S and G2/M phase cells are presented as DNA histogram. (B) The percentage of cells in each cell cycle phase of $\mathrm{MHCC} 97 \mathrm{H}$ after $\mathrm{C}$. cicadae treatment were shown. The data were expressed as mean $\pm \mathrm{SD}$ and were representative of three independent experiments. ${ }^{*}, * *, P<0.05,0.01$, vs. control, respectively.

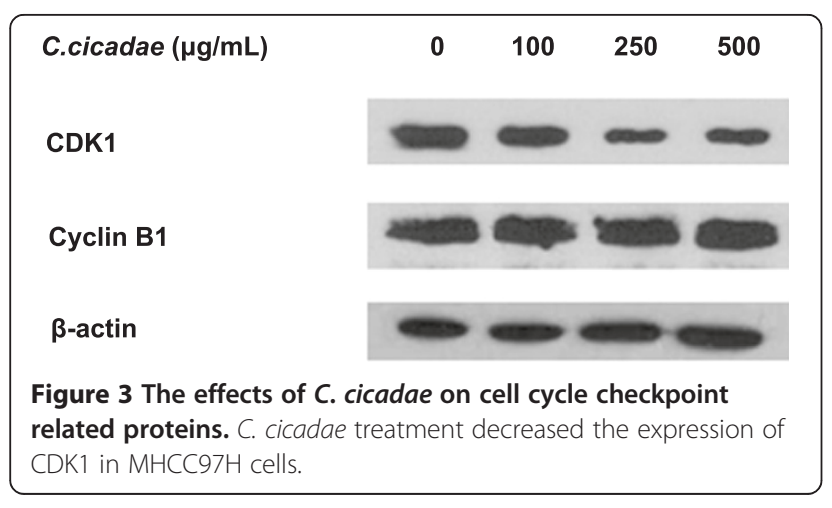

compared with the control cells (Figure 5). These results were similar to those obtained in the proteomic analysis.

\section{Discussion}

Species in the genus Cordyceps can reduce cancer cell proliferation [14,15,55-58], but only limited studies on liver cancer are available. Several polysaccharides isolated from C. cicadae exhibited antitumor and immunomodulatory properties [14,15,55-58] but the mechanisms have not been fully explored. In the present study, we showed that C. cicadae inhibited the growth of the human HCC cell line MHCC97H via G2/M cell cycle arrest. In support 


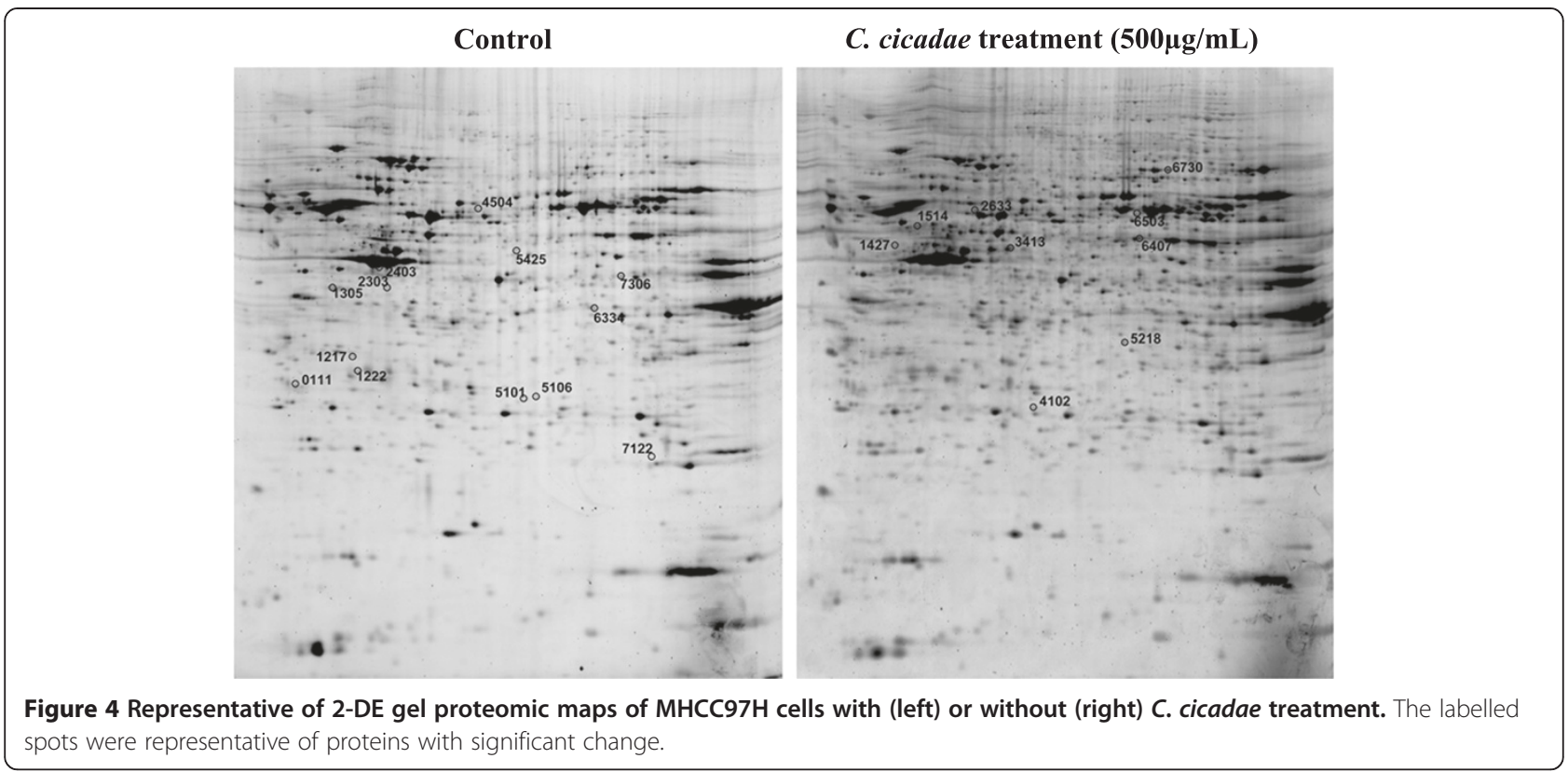

of the cell cycle measurements, several differentially expressed proteins for cell cycle regulation, mitosis, and protein synthesis were identified by the proteomic analysis.

Western blot analyses revealed a decrease in the level of CDK1, which is a G2/M checkpoint cyclin. The cell cycle measurements also indicated accumulation of cells in $\mathrm{G} 2 / \mathrm{M}$ phase rather than induction of apoptosis with C. cicadae. To our knowledge, this is the first study to demonstrate that the anticancer mechanisms of $C$. cicadae involve $\mathrm{G} 2 / \mathrm{M}$ arrest. Other studies showed that $C$. militaris could induce G2/M cell cycle arrest in human colon cancer HT-29 cells [37].

Figure 6 summarizes the magnitude changes in expression of the identified proteins with reference to the control cells. 14-3-3 gamma, BUB3, DCTN2, MAPRE1, GLRX3, and CLIC1 are thought to be involved in cell cycle regulation, G2/M checkpoint control, microtubule polymerization, and spindle organization during mitosis etc. Although their mechanisms related to the G2/M cell cycle arrest induced by C. cicadae were not clear, 14-3-3 gamma is important for cell cycle regulation and 14-3-3 gamma expression change-induced cell cycle deregulation has been implicated in cancer formation [37]. 14-3-3 gamma blocked premature mitotic entry into $\mathrm{G} 2 / \mathrm{M}$ phase after DNA damage [59,60], while 14-3-3 gammaknockdown cells showed inhibition of cdc25C function, which induced overriding of both the incomplete $S$ phase and the G2 DNA damage checkpoint [61]. Overexpression of 14-3-3 gamma in HCC patients was associated with extrahepatic metastasis and worse survival $[62,63]$. Our proteomic data showed that $C$. cicadae treatment reduced the expression of 14-3-3 gamma in the human HCC cell line $\mathrm{MHCC} 97 \mathrm{H}$, suggesting that the anticancer and $\mathrm{G} 2 / \mathrm{M}$ phase arrest effects of $C$. cicadae could be attributed to 14-3-3 gamma expression inhibition.

BUB3, DCTN2, and MAPRE1 are involved in spindle checkpoint and mitosis regulation. BUB3 is a mitosis checkpoint protein for early stages of mitosis to prevent premature sister chromatid separation, missegregation, and aneuploidy via regulation of anaphase-promoting complex/cyclosome (APC/C) $[38,64]$. DCTN2 is involved in functions for the microtubule anchor dynactin complex, inactivation of the spindle checkpoint through kinetochore disassembly, and recruitment of cell cycle regulators to centrosomes $[40,65]$. MAPRE1 is involved in microtubule polymerization, microtubule dynamics control [39], and mitotic spindle function [66], and is dominantly expressed in poorly differentiated HCCs [67]. The expression changes of BUB3, DCTN2, and MAPRE1 in C. cicadae-treated MHCC97H cells indicate a mitosis-regulatory effect of C. cicadae, which may contribute to G2/M phase arrest.

GLRX3 maintains redox homeostasis in living cells [41]. In GLRX3-knockout mice, embryonic fibroblasts were arrested at G2/M phase [68]. CLIC1 is a nuclear chloride ion channel and involved in G2/M cell cycle regulation [42]. These findings may suggest a reason why the expression levels of GLRX3 and CLIC1 were changed in C. cicadae-treated MHCC97H cells.

ENTPD5 is an endoplasmic reticulum (ER) enzyme that hydrolyzes purine nucleoside diphosphates and is essential for liver functions, and ENTPD5-deficiency resulted in hepatocellular neoplasia [69]. Overexpression of ENTPD5 was observed in prostate cancer [43,70]. NDRG1 is a member of the NDRG gene family, and exhibited anticancer and metastasis-suppression effects in pancreatic cancer, colon 
Table 1 Differentially expressed proteins between C. cicadae-treated and non-treated (control) MHCC97H cells

\begin{tabular}{|c|c|c|c|c|c|c|c|c|c|}
\hline $\begin{array}{l}\text { Spot } \\
\text { No. }{ }^{1}\end{array}$ & Protein name & GenInfo identifier $^{2}$ & Protein score $^{3}$ & $\begin{array}{l}\text { Expression quantity } \\
\left(\times 10^{4}\right) \text { control }^{4}\end{array}$ & $\begin{array}{l}\text { Expression quantity } \\
\left(\times 10^{4}\right) \text { C. cicadae }\end{array}$ & $\begin{array}{l}\text { Expression change } \\
\text { (C. Cicadae/control) }\end{array}$ & $P$ & $p 1^{5}$ & $\operatorname{Mr}(\mathrm{kDa})^{5}$ \\
\hline 0111 & 14-3-3 Gamma In Complex With A Phosphoserine Peptide & gi|82407948 & 76 & $33.0 \pm 7.2$ & $19.0 \pm 5.3$ & 0.58 & 0.0004 & 4.80 & 28.3 \\
\hline 1217 & microtubule-associated protein RP/EB family member 1 & gi|6912494 & 219 & $10.0 \pm 3.7$ & $5.7 \pm 2.2$ & 0.57 & 0.026 & 5.02 & 30.1 \\
\hline 1222 & Chloride intracellular channel protein 1 & gi|4588526 & 307 & $24.8 \pm 8.4$ & $9.3 \pm 3.3$ & 0.38 & 0.004112 & 5.02 & 27.2 \\
\hline 1305 & WD-40 repeat protein & gi|4519417 & 221 & $42.3 \pm 10.2$ & $12.0 \pm 4.1$ & 0.28 & 0.001183 & 4.93 & 38.8 \\
\hline 1427 & Tubulin, beta $2 \mathrm{C}$ & gi|23958133 & 188 & $3.6 \pm 1.7$ & $7.8 \pm 4.2$ & 2.17 & 0.025345 & 4.83 & 50.2 \\
\hline 1514 & Dynactin subunit 2 & gi|22096346 & 436 & $9.8 \pm 2.4$ & $19.2 \pm 5.8$ & 1.97 & 0.000491 & 5.10 & 44.3 \\
\hline 2303 & thioredoxin-like protein & gi|3646128 & 123 & $9.3 \pm 5.4$ & $3.4 \pm 1.9$ & 0.37 & 0.038567 & 5.25 & 37.8 \\
\hline 2403 & ACTB protein & gi|15277503 & 444 & $101.7 \pm 33.4$ & $60.3 \pm 18.3$ & 0.59 & 0.001814 & 5.55 & 40.5 \\
\hline 3413 & $\mathrm{~N}$-myc downstream regulated gene 1 & gi|119612570 & 105 & $9.0 \pm 3.3$ & $30.8 \pm 11.8$ & 3.44 & 0.00106 & 5.98 & 34.0 \\
\hline 4102 & heat shock protein beta-1 & gi|4504517 & 368 & $18.1 \pm 7.6$ & $27.7 \pm 10.6$ & 1.53 & 0.026641 & 5.98 & 22.8 \\
\hline 4504 & xaa-Pro dipeptidase isoform 3 & gi|260593665 & 193 & $8.7 \pm 2.7$ & $3.3 \pm 1.2$ & 0.38 & 0.027093 & 5.7 & 48.0 \\
\hline 5101 & Enoyl-CoA delta isomerase 1 , mitochondrial & gi|60593479 & 67 & $11.8 \pm 7.8$ & $5.8 \pm 2.9$ & 0.49 & 0.040511 & 6.00 & 28.9 \\
\hline 5106 & The Protein-Disulfide Isomerase Related Chaperone Erp29 & gi|192987144 & 247 & $16.3 \pm 6.8$ & $9.3 \pm 4.3$ & 0.57 & 0.033331 & 7.07 & 27.2 \\
\hline 5218 & phosphatidylinositol transfer protein beta isoform & gi|6912594 & 181 & $5.5 \pm 1.9$ & $8.5 \pm 2.6$ & 1.56 & 0.004165 & 6.41 & 31.8 \\
\hline 5425 & $\begin{array}{l}\text { ectonucleoside triphosphate diphosphohydrolase } \\
5 \text {, isoform }\end{array}$ & gi|119601555 & 181 & $5.9 \pm 2.1$ & $2.3 \pm 0.8$ & 0.39 & 0.007848 & 5.74 & 45.7 \\
\hline 6334 & hnRNP $2 \mathrm{H} 9 \mathrm{~B}$ & gi|7739445 & 127 & $31.1 \pm 12.6$ & $17.4 \pm 6.5$ & 0.56 & 0.023 & 6.76 & 31.5 \\
\hline 6407 & alpha-enolase isoform 1 & gi|4503571 & 349 & $21.4 \pm 7.5$ & $34.8 \pm 12.6$ & 1.63 & 0.028265 & 7.01 & 47.5 \\
\hline 6730 & WD repeat-containing protein 1 isoform 1 & gi|9257257 & 217 & $9.0 \pm 4.6$ & $13.9 \pm 6.3$ & 1.54 & 0.01346 & 6.17 & 66.8 \\
\hline 7122 & peroxiredoxin 1 & gi|55959887 & 79 & $2.7 \pm 1.0$ & $0.5 \pm 0.1$ & 0.20 & 0.024662 & 6.41 & 19.1 \\
\hline 7306 & mitotic checkpoint protein BUB3 isoform a & gi|4757880 & 147 & $37.1 \pm 17.4$ & $22.1 \pm 10.1$ & 0.60 & 0.045568 & 6.36 & 37.6 \\
\hline
\end{tabular}

${ }^{1}$ Spot no.: automatically assigned by the PDQuest software. ${ }^{2} G e n I n f o$ identifier: sequence identification number assigned by GenBank. ${ }^{3}$ Protein score: generated by the MS identification system.

${ }^{4}$ Expression Quantity were calculated by the PDQuest software, data expressed as mean \pm SD.

${ }^{5} \mathrm{Mr}$ and $p l$ : relative molecular mass $(\mathrm{Mr})$ and isoelectric point $(p l)$ generated by the MS system. 
Table 2 The major bio-functions of identified proteins

\begin{tabular}{|c|c|c|c|c|}
\hline Protein name & Protein symbol & Subcellular location & Protein functions & Up/down regulation \\
\hline \multicolumn{5}{|c|}{ Cell growth and cell cycle regulation } \\
\hline $\begin{array}{l}\text { 14-3-3 Gamma, tyrosine 3-monooxygenase/tryptophan } \\
\text { 5-monooxygenase activation protein, gamma }\end{array}$ & $14-3-3 \gamma$ & Cytoplasm & G2 DNA damage checkpoint [37] & $\downarrow$ \\
\hline mitotic checkpoint protein BUB3 isoform A & BUB3 & Nucleus & $\begin{array}{l}\text { Spindle-assembly checkpoint signalling and establishment of correct } \\
\text { kinetochore-microtubule attachments [38] }\end{array}$ & $\downarrow$ \\
\hline microtubule-associated protein RP/EB family member 1 & MAPRE1 & Cytoplasm & Microtubule polymerization [39] & $\downarrow$ \\
\hline Dynactin subunit 2 & DCTN2 & Cytoplasm & $\begin{array}{l}\text { Modulates cytoplasmic dynein binding to an organelle, and prometaphase } \\
\text { chromosome alignment and spindle organization during mitosis [40] }\end{array}$ & $\uparrow$ \\
\hline thioredoxin-like protein & GLRX3 & Cytoplasm & Human cancer cell growth and metastasis regulation [41] & $\downarrow$ \\
\hline Chloride intracellular channel protein 1 & CLIC1 & $\begin{array}{l}\text { Nucleus membrane, } \\
\text { cell membrane }\end{array}$ & Formation of chloride ion channels, and regulation of the cell cycle [42] & $\downarrow$ \\
\hline \multicolumn{5}{|c|}{ Anti-cancer effects } \\
\hline $\begin{array}{l}\text { ectonucleoside triphosphate diphosphohydrolase } \\
5 \text {, isoform }\end{array}$ & ENTPD5 & $\begin{array}{l}\text { Endoplasmic } \\
\text { reticulum lumen }\end{array}$ & $\begin{array}{l}\text { Promoting glycolysis in proliferating cells in response to phosphoinositide } \\
\text { 3-kinase signalling in the AKT1-PTEN signalling pathway [43] }\end{array}$ & $\downarrow$ \\
\hline N-myc downstream regulated gene 1 & NDRG1 & $\begin{array}{l}\text { Cytoplasm, nucleus, } \\
\text { cell membrane }\end{array}$ & Metastasis suppression [44] & $\uparrow$ \\
\hline heat shock protein beta-1 & HSPB1 & Cytoplasm, nucleus & Stress resistance and actin organization [45] & $\uparrow$ \\
\hline alpha-enolase isoform 1 & ENO1 & $\begin{array}{l}\text { Cytoplasm, cell } \\
\text { membrane }\end{array}$ & $\begin{array}{l}\text { Multifunctional enzyme in various processes such as growth control, hypoxia } \\
\text { tolerance and allergic responses [46] }\end{array}$ & $\uparrow$ \\
\hline \multicolumn{5}{|c|}{ Other functions } \\
\hline xaa-Pro dipeptidase isoform 3 & PEPD & Cytoplasm & Collagen and GSH metabolism [47] & $\downarrow$ \\
\hline Enoyl-CoA delta isomerase 1, mitochondrial & ECl1 & Mitochondrion matrix & & $\downarrow$ \\
\hline $\begin{array}{l}\text { The Protein-Disulfide Isomerase Related Chaperone } \\
\text { Erp29 }\end{array}$ & ERP29 & $\begin{array}{l}\text { Endoplasmic } \\
\text { reticulum lumen }\end{array}$ & $\begin{array}{l}\text { Processing of secretory proteins within the endoplasmic reticulum, possibly } \\
\text { by participating in the folding of proteins in the ER [48] }\end{array}$ & $\downarrow$ \\
\hline phosphatidylinositol transfer protein beta isoform & PITPNB & $\begin{array}{l}\text { Cytoplasm, } \\
\text { Golgi apparatus }\end{array}$ & $\begin{array}{l}\text { Catalyzes the transfer of Ptdlns and phosphatidylcholine between } \\
\text { membranes [49] }\end{array}$ & $\uparrow$ \\
\hline hnRNP 2H9B & HNRNPH3 & Nucleus & $\begin{array}{l}\text { Involved in the splicing process and participates in early heat shock-induced } \\
\text { splicing arrest [50] }\end{array}$ & $\downarrow$ \\
\hline WD repeat-containing protein 1 isoform 1 & WDR1 & Cytoplasm & $\begin{array}{l}\text { Induces disassembly of actin filaments in conjunction with ADF/cofilin } \\
\text { family proteins [51] }\end{array}$ & $\uparrow$ \\
\hline peroxiredoxin 1 & PRDX1 & Cytoplasm & $\begin{array}{l}\text { Involved in redox regulation of the cell. Reduces peroxides with reducing } \\
\text { equivalents provided through the thioredoxin system but not from } \\
\text { glutaredoxin [52] }\end{array}$ & $\downarrow$ \\
\hline $\begin{array}{l}\text { WD-40 repeat protein, serine/threonine kinase receptor } \\
\text { associated protein }\end{array}$ & STRAP & Cytoplasm, nucleus & $\begin{array}{l}\text { The SMN complex plays an essential role in spliceosomal snRNP assembly in } \\
\text { the cytoplasm and is required for pre-mRNA splicing in the nucleus }[53,54]\end{array}$ & $\downarrow$ \\
\hline
\end{tabular}




C.cicadae $(\boldsymbol{\mu g} / \mathrm{mL})$
HSP27

cancer, cervical and ovarian cancer, prostate cancer, and breast cancer [44,71-73]. MHCC97H cells exhibited an $80 \%$ pulmonary metastatic rate when injected into nude mice [74]. HSPB1 is a subunit of HSP27, and suppressed cell apoptosis in MHCC97H cells via an NF-kappaB pathway [45]. The elevation of this protein indicated some resistance of the cancer cells, and could be responsible for the absence of apoptosis in the C. cicadae-treated cancer cells. ENO1, a glycolysis module protein, was overexpressed in HCC cells [46,75], and its increased level suggests that $C$. cicadae treatment increased the glycolytic activity of the cancer cells.
A reduction in PEPD is involved in collagen and GSH metabolism of C. cicadae. PEPD is a homodimeric iminodipeptidase that releases carboxy-terminal proline or hydroxyproline residues from oligopeptides, and is used as a marker of non-alcoholic liver fibrosis $[47,76]$. ERP29 works in the early secretory pathway in the ER, and overexpression of ERP29 resulted in higher expression of HSP27 in breast cancer cells [48]. The reduced expression of ERP29 is likely to be attributed to reduced ER stress with treatment of $C$. cicadae.

STRAP is involved in spliceosomal mRNP assembly in the cytoplasm and pre-mRNA splicing in the nucleus [53]. Overexpression of STRAP was reported in several cancers [53,77]. A STRAP-activated p53-related apoptosisinduction effect and higher expression of STRAP in drugtreated HCC cells were observed [54,78]. In the present study, the expression of STRAP was reduced, which may be related to the non-apoptotic effect of $C$. cicadae.

PRDX1 is a member of the peroxiredoxin family involved in redox regulation in cells, regulation of hydrogen peroxide signaling through its peroxidase activity, and a protein chaperone function. The aspect of whether the reduced expression of PRDX1 contributes to reduced survival of $\mathrm{MHCC} 97 \mathrm{H}$ cells via failure in redox regulation against reactive oxygen species remains to be determined. Elevated expression of PRDX1 was found in various cancers $[52,79,80]$.

The present study has identified novel molecular signatures in C. cicadae-induced cell cycle arrest and cell death in MHCC97H cells using proteomics. Among the

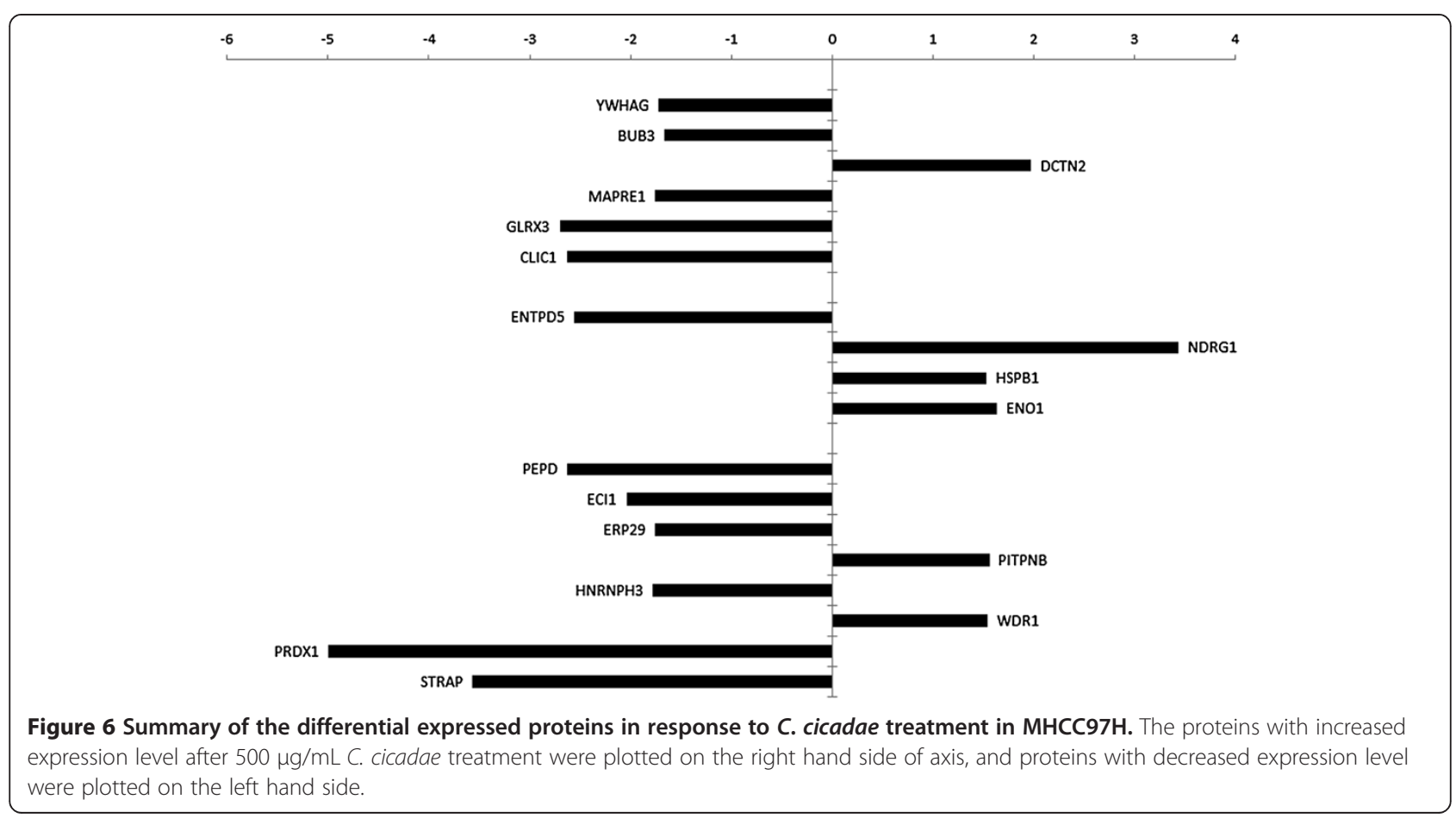


differentially expressed proteins identified, 14-3-3 gamma, BUB3, DCTN2, MAPRE1, GLRX3, and CLIC1 may play some significant roles in the $C$. cicadae-induced G2/M phase arrest in MHCC $97 \mathrm{H}$ cells. The identified proteins will further enhance a molecular explanation for the cell cycle arrest process induced by $C$. cicadae. Further validation of these markers in gene knockout studies would greatly improve our understanding of the molecular mechanisms behind the liver cancer therapy potential of C. cicadae.

\section{Conclusions}

The water extract of $C$. cicadae reduced the growth of the human HCC cell line MHCC97H via G2/M cell cycle arrest.

\section{Competing interests}

The authors declare that they have no competing interests.

\section{Authors' contributions}

HW and JMFW conceived and designed the study. HLW, ZJ and WHS performed experiments. HLW performed data analysis. HW, CYJL and JMFW wrote the manuscript. All authors read and approved the final version of the manuscript.

\section{Acknowledgments}

This work was supported by the Chinese Medicine Research Fund funded by BioAsia (Institute of Life Sciences Shanghai Pan Asia, Shanghai, China] and partially funded by Seed Funding Programme for Basic Research funded by the University of Hong Kong.

\section{Author details}

${ }^{1}$ Food and Nutrition Division, School of Biological Sciences, The University of Hong Kong, Pokfulam Road, Hong Kong, SAR, China. ${ }^{2}$ School of Biology and Pharmaceutical Engineering, Wuhan Polytechnic University, Wuhan, Hubei, China.

Received: 18 November 2013 Accepted: 30 April 2014

Published: 8 May 2014

\section{References}

1. Ferlay JSH, Bray F, Forman D, Mathers C, Parkin DM: Cancer Incidence and Mortality Worldwide: IARC CancerBase No. 10. 2008. http://globocan.iarc. fr/Default.aspx.

2. Shiu WC: Primary liver cancer in Hong Kong. Cancer Chemother Pharmacol 1992, 31(Suppl):S143-S145.

3. Chen JG, Zhang SW: Liver cancer epidemic in China: past, present and future. Semin Cancer Biol 2011, 21:59-69.

4. Chao J, Chang ET, So SK: Hepatitis B and liver cancer knowledge and practices among healthcare and public health professionals in China: a cross-sectional study. BMC Public Health 2010, 10:98.

5. Wu P, Dugoua JJ, Eyawo O, Mills EJ: Traditional Chinese Medicines in the treatment of hepatocellular cancers: a systematic review and meta-analysis. J Exp Clin Cancer Res 2009, 28:112.

6. Winkler D: Yartsa Gunbu (Cordyceps sinensis) and the Fungal Commodification of Tibet's Rural Economy. Econ Bot 2008, 62:291-305.

7. Li FH, Liu P, Xiong WG, Xu GF: [Effects of Cordyceps sinensis on dimethylnitrosamine-induced liver fibrosis in rats]. Zhong $X_{i} Y_{i}$ Jie He Xue Bao 2006, 4:514-517.

8. Wu JY, Zhang QX, Leung PH: Inhibitory effects of ethyl acetate extract of Cordyceps sinensis mycelium on various cancer cells in culture and B16 melanoma in C57BL/6 mice. Phytomedicine 2007, 14:43-49.

9. Zhang $\mathrm{Q}, \mathrm{Wu} J, \mathrm{Hu} \mathrm{Z}, \mathrm{Li} \mathrm{D}$ : Induction of $\mathrm{HL}-60$ apoptosis by ethyl acetate extract of Cordyceps sinensis fungal mycelium. Life Sci 2004, 75:2911-2919.

10. Yang HY, Leu SF, Wang YK, Wu CS, Huang BM: Cordyceps sinensis mycelium induces MA-10 mouse Leydig tumor cell apoptosis by activating the caspase- 8 pathway and suppressing the NF-kappaB pathway. Arch Androl 2006, 52:103-110.

11. Nakamura K, Konoha K, Yamaguchi Y, Kagota S, Shinozuka K, Kunitomo M: Combined effects of Cordyceps sinensis and methotrexate on hematogenic lung metastasis in mice. Receptors Channels 2003, 9:329-334.

12. Kubo E, Yoshikawa N, Kunitomo M, Kagota S, Shinozuka K, Nakamura K: Inhibitory effect of Cordyceps sinensis on experimental hepatic metastasis of melanoma by suppressing tumor cell invasion. Anticancer Res 2010, 30:3429-3433.

13. Park C, Hong SH, Lee JY, Kim GY, Choi BT, Lee YT, Park DI, Park YM, Jeong YK, Choi YH: Growth inhibition of U937 leukemia cells by aqueous extract of Cordyceps militaris through induction of apoptosis. Oncol Rep 2005, 13:1211-1216.

14. Lee H, Kim YJ, Kim HW, Lee DH, Sung MK, Park T: Induction of apoptosis by Cordyceps militaris through activation of caspase-3 in leukemia HL-60 cells. Biol Pharm Bull 2006, 29:670-674.

15. Park SE, Yoo HS, Jin CY, Hong SH, Lee YW, Kim BW, Lee SH, Kim WJ, Cho CK, Choi YH: Induction of apoptosis and inhibition of telomerase activity in human lung carcinoma cells by the water extract of Cordyceps militaris. Food Chem Toxicol 2009, 47:1667-1675.

16. Park SE, Kim J, Lee YW, Yoo HS, Cho CK: Antitumor activity of water extracts from Cordyceps militaris in $\mathrm{NCl}-\mathrm{H} 460$ cell xenografted nude mice. J Acupunct Meridian Stud 2009, 2:294-300.

17. Jin CY, Kim GY, Choi YH: Induction of apoptosis by aqueous extract of Cordyceps militaris through activation of caspases and inactivation of Akt in human breast cancer MDA-MB-231 Cells. J Microbiol Biotechnol 2008, 18:1997-2003.

18. Lee SJ, Kim SK, Choi WS, Kim WJ, Moon SK: Cordycepin causes p21WAF1-mediated G2/M cell-cycle arrest by regulating c-Jun $\mathrm{N}$-terminal kinase activation in human bladder cancer cells. Arch Biochem Biophys 2009, 490:103-109.

19. Yoshikawa N, Kunitomo M, Kagota S, Shinozuka K, Nakamura K: Inhibitory effect of cordycepin on hematogenic metastasis of B16-F1 mouse melanoma cells accelerated by adenosine-5'-diphosphate. Anticancer Res 2009, 29:3857-3860.

20. Wu WC, Hsiao JR, Lian YY, Lin CY, Huang BM: The apoptotic effect of cordycepin on human OEC-M1 oral cancer cell line. Cancer Chemother Pharmacol 2007, 60:103-111.

21. Choi S, Lim MH, Kim KM, Jeon BH, Song WO, Kim TW: Cordycepin-induced apoptosis and autophagy in breast cancer cells are independent of the estrogen receptor. Toxicol Appl Pharmacol 2011, 257:165-173.

22. Jeong JW, Jin CY, Park C, Hong SH, Kim GY, Jeong YK, Lee JD, Yoo YH, Choi $\mathrm{YH}$ : Induction of apoptosis by cordycepin via reactive oxygen species generation in human leukemia cells. Toxicol In Vitro 2011, 25:817-824.

23. Ukai S, Kiho T, Hara C, Morita M, Goto A, Imaizumi N, Hasegawa Y: Polysaccharides in fungi. XIII. Antitumor activity of various polysaccharides isolated from Dictyophora indusiata, Ganoderma japonicum, Cordyceps cicadae, Auricularia auricula-judae, and Auricularia species. Chem Pharm Bull (Tokyo) 1983, 31:741-744.

24. Yang JZ, Zhuo J, Chen BK, Jin LQ, Lv JX, Li L: [Regulating effects of Paecilomyces cicadae polysaccharides on immunity of aged rats] Zhongguo Zhong Yao Za Zhi 2008, 33:292-295.

25. Zhu R, Chen YP, Deng YY, Zheng R, Zhong YF, Wang L, Du LP: Cordyceps cicadae extracts ameliorate renal malfunction in a remnant kidney model. J Zhejiang Univ Sci B 2011, 12:1024-1033.

26. Weng SC, Chou CJ, Lin LC, Tsai WJ, Kuo YC: Immunomodulatory functions of extracts from the Chinese medicinal fungus Cordyceps cicadae. $J$ Ethnopharmacol 2002, 83:79-85.

27. Kim HS, Kim JY, Ryu HS, Shin BR, Kang JS, Kim HM, Kim YO, Hong JT, Kim Y, Han SB: Phenotypic and functional maturation of dendritic cells induced by polysaccharide isolated from Paecilomyces cicadae. J Med Food 2011, 14:847-856.

28. Kuo YC, Weng SC, Chou CJ, Chang TT, Tsai WJ: Activation and proliferation signals in primary human $\mathrm{T}$ lymphocytes inhibited by ergosterol peroxide isolated from Cordyceps cicadae. Br J Pharmacol 2003, 140:895-906.

29. Zhu R, Zheng R, Deng Y, Chen Y, Zhang S: Ergosterol peroxide from Cordyceps cicadae ameliorates TGF-beta1-induced activation of kidney fibroblasts. Phytomedicine 2013, 21(3):372-378.

30. Ju-fen JZ-m CAl, Hong-yang LU, Bo-zheng LU: Research of Anti - tumor Effects of Different Purified Components of Cordyceps Cicadae in Vitro. Chin Arch Tradit Chin Med 2010, 28:5. 
31. Jin $L-Q$, Xiong Z-K, Lu J-X: Experimental studies on immunomodulatory and antitumor activity of polysaccharide from Paecilomyces cicadidae. Chinese Journal of Pathophysiology 2008, 24:4.

32. Hondermarck H: Proteomics: Biomedical and Pharmaceutical Applications. Dordrecht: Kluwer Academic Publishers; 2004.

33. Rajcevic U, Niclou SP, Jimenez CR: Proteomics strategies for target identification and biomarker discovery in cancer. Front Biosci 2009, 14:3292-3303.

34. Lee CY, Sit WH, Fan ST, Man K, Jor IW, Wong LL, Wan ML, Tan-Un KC, Wan JM: The cell cycle effects of docosahexaenoic acid on human metastatic hepatocellular carcinoma proliferation. Int J Oncol 2010, 36:991-998.

35. Jiang P, Siggers $J$, Ngai HH, Sit WH, Sangild PT, Wan JM: The small intestine proteome is changed in preterm pigs developing necrotizing enterocolitis in response to formula feeding. J Nutr 2008, 138:1895-1901.

36. Ferrell JE Jr, Wu M, Gerhart JC, Martin GS: Cell cycle tyrosine phosphorylation of p34cdc2 and a microtubule-associated protein kinase homolog in Xenopus oocytes and eggs. Mol Cell Biol 1991, 11:1965-1971.

37. Hermeking $H$, Benzinger $A: 14-3-3$ proteins in cell cycle regulation. Semin Cancer Biol 2006, 16:183-192.

38. Lopes CS, Sampaio P, Williams B, Goldberg M, Sunkel CE: The Drosophila Bub3 protein is required for the mitotic checkpoint and for normal accumulation of cyclins during G2 and early stages of mitosis. J Cell Sci 2005, 118:187-198

39. Honnappa S, Gouveia SM, Weisbrich A, Damberger FF, Bhavesh NS, Jawhari H, Grigoriev I, van Rijssel FJA, Buey RM, Lawera A, Jelesarov I, Winkler FK, Wüthrich K, Akhmanova A, Steinmetz MO: An EB1-Binding Motif Acts as a Microtubule Tip Localization Signal. Cell 2009, 138:366-376.

40. Quintyne NJ, Schroer TA: Distinct cell cycle-dependent roles for dynactin and dynein at centrosomes. J Cell Biol 2002, 159:245-254.

41. Haunhorst P, Hanschmann EM, Brautigam L, Stehling O, Hoffmann B, Muhlenhoff $U$, Lill R, Berndt C, Lillig CH: Crucial function of vertebrate glutaredoxin 3 (PICOT) in iron homeostasis and hemoglobin maturation. Mol Biol Cell 2013, 24:1895-1903.

42. Valenzuela SM, Mazzanti M, Tonini R, Qiu MR, Warton K, Musgrove EA Campbell TJ, Breit SN: The nuclear chloride ion channel NCC27 is involved in regulation of the cell cycle. J Physiol 2000, 529(Pt 3):541-552.

43. Villar J, Quadri HS, Song I, Tomita Y, Tirado OM, Notario V: PCPH/ENTPD5 Expression Confers to Prostate Cancer Cells Resistance against Cisplatin-Induced Apoptosis through Protein Kinase Ca-Mediated Bcl-2 Stabilization. Cancer Res 2009, 69:102-110.

44. Angst E, Dawson DW, Stroka D, Gloor B, Park J, Candinas D, Reber HA, Hines OJ, Eibl G: N-myc downstream regulated gene-1 expression correlates with reduced pancreatic cancer growth and increased apoptosis in vitro and in vivo. Surgery 2011, 149:614-624.

45. Guo K, Kang NX, Li Y, Sun L, Gan L, Cui FJ, Gao MD, Liu KY: Regulation of HSP27 on NF-kappaB pathway activation may be involved in metastatic hepatocellular carcinoma cells apoptosis. BMC Cancer 2009, 9:100.

46. Hamaguchi T, lizuka N, Tsunedomi R, Hamamoto Y, Miyamoto T, lida M, Tokuhisa Y, Sakamoto K, Takashima M, Tamesa T, Oka M: Glycolysis module activated by hypoxia-inducible factor 1alpha is related to the aggressive phenotype of hepatocellular carcinoma. Int J Oncol 2008, 33:725-731.

47. Horoz M, Aslan M, Bolukbas FF, Bolukbas C, Nazligul Y, Celik H, Aksoy N: Serum prolidase enzyme activity and its relation to histopathological findings in patients with non-alcoholic steatohepatitis. J Clin Lab Anal 2010, 24:207-211.

48. Zhang D, Putti TC: Over-expression of ERp29 attenuates doxorubicin-induced cell apoptosis through up-regulation of Hsp27 in breast cancer cells. Exp Cell Res 2010, 316:3522-3531.

49. Carvou N, Holic R, Li M, Futter C, Skippen A, Cockcroft S: Phosphatidylinositoland phosphatidylcholine-transfer activity of PITPbeta is essential for COPI-mediated retrograde transport from the Golgi to the endoplasmic reticulum. J Cell Sci 2010, 123:1262-1273.

50. Garneau D, Revil T, Fisette J-F, Chabot B: Heterogeneous Nuclear Ribonucleoprotein F/H Proteins Modulate the Alternative Splicing of the Apoptotic Mediator Bcl-x. J Biol Chem 2005, 280:22641-22650.

51. Fujibuchi T, Abe Y, Takeuchi T, Imai Y, Kamei Y, Murase R, Ueda N, Shigemoto K, Yamamoto H, Kito K: AIP1/WDR1 supports mitotic cell rounding. Biochem Biophys Res Commun 2005, 327:268-275.

52. Noh DY, Ahn SJ, Lee RA, Kim SW, Park IA, Chae HZ: Overexpression of peroxiredoxin in human breast cancer. Anticancer Res 2001, 21:2085-2090.

53. Halder SK, Anumanthan G, Maddula R, Mann J, Chytil A, Gonzalez AL, Washington MK, Moses HL, Beauchamp RD, Datta PK: Oncogenic function of a novel WD-domain protein, STRAP, in human carcinogenesis. Cancer Res 2006, 66:6156-6166.

54. Jung $\mathrm{H}$, Seong $\mathrm{HA}, \mathrm{Ha} H$ : NM23-H1 tumor suppressor and its interacting partner STRAP activate p53 function. J Biol Chem 2007, 282:35293-35307.

55. Jiang J, Sliva D: Novel medicinal mushroom blend suppresses growth and invasiveness of human breast cancer cells. Int J Oncol 2010, 37:1529-1536.

56. Marchbank T, Ojobo E, Playford CJ, Playford RJ: Reparative properties of the traditional Chinese medicine Cordyceps sinensis (Chinese caterpillar mushroom) using HT29 cell culture and rat gastric damage models of injury. Br J Nutr 2011, 105:1303-1310.

57. Kim HG, Song H, Yoon DH, Song BW, Park SM, Sung GH, Cho JY, Park HI, Choi S, Song WO, Hwang KC, Kim TW: Cordyceps pruinosa extracts induce apoptosis of HeLa cells by a caspase dependent pathway. J Ethnopharmacol 2010, 128:342-351.

58. Oh JY, Baek YM, Kim SW, Hwang HJ, Hwang HS, Lee SH, Yun JW: Apoptosis of human hepatocarcinoma (HepG2) and neuroblastoma (SKN-SH) cells induced by polysaccharides-peptide complexes produced by submerged mycelial culture of an entomopathogenic fungus Cordyceps sphecocephala. J Microbiol Biotechnol 2008, 18:512-519.

59. Dalal SN, Yaffe MB, DeCaprio JA: 14-3-3 family members act coordinately to regulate mitotic progression. Cell Cycle 2004, 3:672-677.

60. Kasahara K, Goto H, Enomoto M, Tomono Y, Kiyono T, Inagaki M: 14-3-3gamma mediates Cdc25A proteolysis to block premature mitotic entry after DNA damage. EMBO J 2010, 29:2802-2812.

61. Hosing AS, Kundu ST, Dalal SN: 14-3-3 Gamma is required to enforce both the incomplete $S$ phase and G2 DNA damage checkpoints. Cell Cycle 2008, 7:3171-3179

62. Lee IN, Chen CH, Sheu JC, Lee HS, Huang GT, Yu CY, Lu FJ, Chow LP. Identification of human hepatocellular carcinoma-related biomarkers by two-dimensional difference gel electrophoresis and mass spectrometry. $J$ Proteome Res 2005, 4:2062-2069.

63. Ko BS, Lai IR, Chang TC, Liu TA, Chen SC, Wang J, Jan YJ, Liou JY: Involvement of 14-3-3gamma overexpression in extrahepatic metastasis of hepatocellular carcinoma. Hum Pathol 2011, 42:129-135.

64. Logarinho E, Resende T, Torres C, Bousbaa H: The human spindle assembly checkpoint protein Bub3 is required for the establishment of efficient kinetochore-microtubule attachments. Mol Biol Cell 2008, 19:1798-1813.

65. Howell BJ, McEwen BF, Canman JC, Hoffman DB, Farrar EM, Rieder CL, Salmon ED: Cytoplasmic dynein/dynactin drives kinetochore protein transport to the spindle poles and has a role in mitotic spindle checkpoint inactivation. J Cell Biol 2001, 155:1159-1172.

66. Green RA, Wollman R, Kaplan KB: APC and EB1 function together in mitosis to regulate spindle dynamics and chromosome alignment. Mol Biol Cell 2005, 16:4609-4622.

67. Orimo T, Ojima H, Hiraoka N, Saito S, Kosuge T, Kakisaka T, Yokoo H, Nakanishi K, Kamiyama T, Todo S, Hirohashi S, Kondo T: Proteomic profiling reveals the prognostic value of adenomatous polyposis coli-end-binding protein 1 in hepatocellular carcinoma. Hepatology 2008, 48:1851-1863.

68. Cheng NH, Zhang W, Chen WQ, Jin J, Cui X, Butte NF, Chan L, Hirschi KD: A mammalian monothiol glutaredoxin, Grx3, is critical for cell cycle progression during embryogenesis. FEBS J 2011, 278:2525-2539.

69. Read R, Hansen G, Kramer J, Finch R, Li L, Vogel P: Ectonucleoside triphosphate diphosphohydrolase type 5 (Entpd5)-deficient mice develop progressive hepatopathy, hepatocellular tumors, and spermatogenic arrest. Vet Pathol 2009, 46:491-504.

70. Villar J, Arenas MI, MacCarthy CM, Blanquez MJ, Tirado OM, Notario V: PCPH/ENTPD5 expression enhances the invasiveness of human prostate cancer cells by a protein kinase $C$ delta-dependent mechanism. Cancer Res 2007, 67:10859-10868.

71. Bandyopadhyay S, Pai SK, Hirota S, Hosobe S, Tsukada T, Miura K, Takano Y, Saito K, Commes T, Piquemal D, Watabe M, Gross S, Wang Y, Huggenvik J, Watabe K: PTEN up-regulates the tumor metastasis suppressor gene Drg-1 in prostate and breast cancer. Cancer Res 2004, 64:7655-7660.

72. Li Q, Chen H: Transcriptional silencing of N-Myc downstream-regulated gene 1 (NDRG1) in metastatic colon cancer cell line SW620. Clin Exp Metastasis 2011, 28:127-135.

73. Zhao G, Chen J, Deng Y, Gao F, Zhu J, Feng Z, Lv X, Zhao Z: Identification of NDRG1-regulated genes associated with invasive potential in cervical and ovarian cancer cells. Biochem Biophys Res Commun 2011, 408:154-159.

74. Li YL, Tang ZT, Ye SY, Liu BL, Liu YL, Chen JC, Xue QX: Establishment of a hepatocellular carcinoma cell line with unique metastatic characteristics 
through in vivo selection and screening for metastasis-related genes through cDNA microarray. J Cancer Res Clin Oncol 2003, 129:43-51.

75. Takashima M, Kuramitsu Y, Yokoyama Y, lizuka N, Fujimoto M, Nishisaka T, Okita K, Oka M, Nakamura K: Overexpression of alpha enolase in hepatitis C virus-related hepatocellular carcinoma: association with tumor progression as determined by proteomic analysis. Proteomics 2005, 5:1686-1692.

76. Kayadibi H, Gultepe M, Yasar B, Ince AT, Ozcan O, Ipcioglu OM, Kurdas OO, Bolat B, Benek YZ, Guveli H, Atalay S, Ozkara S, Keskin O: Diagnostic value of serum prolidase enzyme activity to predict the liver histological lesions in non-alcoholic fatty liver disease: a surrogate marker to distinguish steatohepatitis from simple steatosis. Dig Dis Sci 2009, 54:1764-1771.

77. Matsuda S, Katsumata R, Okuda T, Yamamoto T, Miyazaki K, Senga T, Machida K, Thant AA, Nakatsugawa S, Hamaguchi M: Molecular cloning and characterization of human MAWD, a novel protein containing WD-40 repeats frequently overexpressed in breast cancer. Cancer Res 2000, 60:13-17.

78. Wang H, Ye Y, Pan SY, Zhu GY, Li YW, Fong DW, Yu ZL: Proteomic identification of proteins involved in the anticancer activities of oridonin in HepG2 cells. Phytomedicine 2011, 18:163-169.

79. Qi Y, Chiu JF, Wang L, Kwong DL, He QY: Comparative proteomic analysis of esophageal squamous cell carcinoma. Proteomics 2005, 5:2960-2971.

80. Shen J, Person MD, Zhu J, Abbruzzese JL, Li D: Protein expression profiles in pancreatic adenocarcinoma compared with normal pancreatic tissue and tissue affected by pancreatitis as detected by two-dimensional gel electrophoresis and mass spectrometry. Cancer Res 2004, 64:9018-9026.

\section{doi:10.1186/1749-8546-9-15}

Cite this article as: Wang et al: Cordyceps cicadae induces G2/M cell cycle arrest in MHCC97H human hepatocellular carcinoma cells: a proteomic study. Chinese Medicine 2014 9:15.

\section{Submit your next manuscript to BioMed Central and take full advantage of:}

- Convenient online submission

- Thorough peer review

- No space constraints or color figure charges

- Immediate publication on acceptance

- Inclusion in PubMed, CAS, Scopus and Google Scholar

- Research which is freely available for redistribution 